\title{
Sexual Orientation and the European Convention on Human Rights: What of
}

\author{
the ' $L$ ' in LGBT?
}

\section{Loveday Hodson}

Associate Professor in Law, University of Leicester, UK.

\begin{abstract}
\end{abstract}
\section{Introduction}

The European Court of Human Rights ('ECtHR', or 'the Court') has been at the heart of remarkable and widely-celebrated developments towards recognising and securing LGBT rights. ${ }^{1}$ As Paul Johnson has written: "Human rights discourse has become one of the most effective vehicles for mobilizing a range of moral and political claims that contest the widespread social and legal discrimination experienced by sexual minorities". ${ }^{2}$ The past 60 years have been significant ones in which, despite its early reticence, the ECtHR has set a number of international bench-marks for gay rights: ${ }^{3}$ most strikingly, declaring the criminalisation of male same-sex activity to be a violation of the right to private life ${ }^{4}$ forging the path for gender recognition of trans persons; ${ }^{5}$

\footnotetext{
${ }^{1}$ Throughout this paper I use 'LGBT' as short-hand for the cases related to sexual orientation and gender identity before the Court, as well as the applicants that bring those cases. The Court and Commission have tended to use the terms 'homosexual' and 'transsexual', which I sometimes adopt when discussing the Court's decisions.

2 Johnson, P. (2013) Homosexuality and the European Court of Human Rights (Abingdon: Routledge), at 2 .

${ }^{3}$ More recently, the Inter-American Court of Human Rights has broken ground in its Advisory Opinion State Obligations Concerning Change of Name, Gender Identity, and Rights Derived from a Relationship Between Same-Sex Couples (Interpretation and Scope of Articles 1(1), 3, 7, 11(2), 13, 17, 18 and 24, in relation to Article 1, of the American Convention on Human Rights), OC-24/17, Series A No. 24 (24 November 2018).

${ }^{4}$ Dudgeon $v$ the United Kingdom, (1981) 4 EHRR 149.

${ }^{5}$ Goodwin v the United Kingdom, (2002) 35 EHRR 447.
} 
including sexual orientation among the grounds of prohibited discrimination under the European Convention on Human Rights ('ECHR' or 'the Convention'); ${ }^{6}$ and, more recently, beginning to address the complex and contested area of relationship recognition. $^{7}$

This paper, inspired by intersectional feminism of authors such as Kimberlé Crenshaw, critically examines the trajectory of the Court's LGBT case-law from a gendered perspective, and foregrounds the portrayal, experience, and, indeed, invisibility, of lesbian applicants. ${ }^{8}$ In particular, it considers the important question of whether adopting an intersectional approach that considers the gender dimension of sexual orientation claims provides a somewhat different perspective on the struggle for LGBT rights before the ECtHR. The Court, based in Strasbourg, is the most prolific human rights tribunal and certainly has the lengthiest history of engagement with LGBT rights. It is common place to assert that gender plays a significant role in how rights violations are constructed, experienced, and responded to. ${ }^{9}$ It seems important to question, then, what would happen to our understanding of the history of the progress made with respect to the rights of sexual minorities if the ' $L$ ' were to be disaggregated from the LGBT?

\footnotetext{
${ }^{6}$ Smith and Grady $v$ the United Kingdom, (1999) 29 EHRR 493.

${ }^{7}$ See, for instance, Schalk and Kopf v Austria, (2011) 53 EHRR 20.

${ }^{8}$ On the invisibility of lesbians in international law more generally, see, for example, Otto, D. (1995), 'Lesbians? Not in My Country' 20 Alternative Law Journal 288-290.

${ }^{9}$ See, for example: Bunch, C. (1990), 'Women's Rights are Human Rights: Toward a Re-vision of Human Rights' 12 Human Rights Quarterly 486. Binion, G (1995), 'Human Rights: A Feminist Perspective', 17(3) Human Rights Quarterly 509; Meyersfeld, B.C. (2003-2004), 'Reconceptualizing Domestic Violence in International Law' 67 Albany Law Review 371; Otto, D. (2006) 'Lost in translation: Re-scripting the sexed subjects of international human rights law' in Orford, A., ed., (2006), International Law and its Others (Cambridge: Cambridge University Press).
} 
A key function of international human rights law is to construct the rights-bearing subject (a process that invests the subject with the capacity to bring claims against the State). In this paper, I argue that the success of gay rights cases in Strasbourg has been constructed on the back of an autonomous, masculine, subject. I consider some of the gendered exclusions that may arise from this particular construction of subject-hood through an overview of its 'L' cases. Ultimately, I argue that the much of the Court's LGBT case-law has served to reinforce patriarchal norms and values, rendering it largely unresponsive to the particular demands and rights of lesbian women. While accepting that the emergence of the ECHR's gay subject has undoubtedly been important for lesbian women's rights, and much to be celebrated in the shared struggle for LGBT rights, the invisibility and exclusion of lesbian subject-hood in international human rights law is, it is suggested, nonetheless worthy of discussion.

\section{Making Heady Progress? The European Court's Construction of Gay Identity and Sexuality}

The ECHR has undoubtedly provided an important platform for the progression of LGBT rights over the past sixty years. There are a number of comprehensive and excellent studies of the lengthy history of LGBT cases before the ECtHR. ${ }^{10}$ What I wish to reflect on in particular here is how LGBT applicants and their claims have depended on a particular construction of gay sexuality and sexual identity. Judith Butler has stressed the significance of the construction of subject-hood as follows:

\footnotetext{
${ }^{10}$ See, for instance, Johnson, supra n. 2; Wintemute, R (1995) Sexual Orientation and Human Rights: The United States Constitution, the European Convention, and the Canadian Charter (Oxford: Clarendon Press).
} 
The notion of the subject carries with it a doubleness that is crucial to emphasise: the subject is one who is presumed to be the presupposition of agency...but the subject is also subjected to a set of rules or laws that precede the subject....11

Subject-hood is, thus, a double-edged sword; it is, nonetheless, crucial to identity-based rights claims. A review of the Court's case law - as well as the decisions of the nowabolished Commission, which acted as an initial tier in the decision-making process in Strasbourg - indicates that the approach taken in Strasbourg to LGBT subject-hood has been at best tentative with respect to lesbian identities and sexualities and, consequently, to the furtherance of the rights of lesbian women.

The first application that overtly addressed an issue of sexual orientation under the ECHR was W.B. v Germany, a 1955 case brought to the Commission in the name of individual man to challenge his criminal convictions, and subsequent imprisonment, for homosexual activity. The Commission's response was to tersely reject his claim as inadmissible on the grounds that the criminal law provision in question was a permissible interference with privacy rights for the purpose protecting public health and morals. Although that case was followed by a string of similar, unsuccessful applications attempting to challenge criminal law provisions, it nonetheless laid important foundations. Strikingly, given the absence of any explicit reference to sexuality in the Convention, from this beginning gay male sexuality, albeit abhorrently

\footnotetext{
${ }^{11}$ Judith Butler quoted in Meijer, I. C. and Prins, B., (Winter, 1998), 'How Bodies Come to Matter: An Interview with Judith Butler', (23:2) Signs, 275-286 at 285.
} 
characterised as threatening to the social fabric, was never held to be beyond the Convention's remit.

Thus, the first significant step in the construction of gay identity in Strasbourg was to frame the applicants' claim as a question of interference with the right to private life (Article 8): in framing LGBT rights in terms of claiming a sphere of privacy against State regulation, men's sexual agency was understood as an innate, intimate, part of their being. The applicant in a 1960 case, A.S. v Federal Republic of Germany, for instance, claimed that homosexuals "have an innate propensity towards it, which is the case with him". The subject's humanity - including his sexual citizenship - was thereby in fact confirmed even in the numerous early unsuccessful cases brought by men to challenge repressive criminal laws. ${ }^{12}$ Laws - and human rights laws are not exempt from this - play an important role in the construction of LGBT identity.

For the following twenty years, the Commission's LGBT cases (of which there were almost twenty) exclusively concerned challenges to the criminalisation of consensual sexual activity between men, a line of cases that eventually led to a successful outcome in the Dudgeon v the United Kingdom judgment of 1981. In Dudgeon, the Court referred to the Wolfenden Report's view that it was not the role of the criminal law "to intervene in the private lives of citizens, or to seek to enforce any particular pattern of behaviour, further than is necessary..."13 For this Court, the pioneering applicant was an autonomous being, for whom sexuality was the expression of "a most intimate aspect of private life". ${ }^{14}$ Further, the applicant's sexuality was defined in binary opposition to

\footnotetext{
${ }^{12}$ For an overview of the unsuccessful case that preceded Dudgeon, see Chapter 1 in Johnson, supra n. 2.

${ }^{13}$ Dudgeon, supra n. 4 at para 17.

14 ibid at para 52.
} 
the heterosexual male: Jeffrey Dudgeon was described by the Court as being "consciously homosexual from the age of 14". Marilyn Frye observed of the struggle against laws regulating particular male same-sex behaviour:

It is refusing a limitation on phallic access; it is a refusal to restrain the male self. It is an excess of phallic arrogance. The fundamental principle is that of universal phallic access. What is in dispute is only a qualification of it. ${ }^{15}$

While this clearly does not represent the end of contemporary gay/queer movements, my argument is simply that the unquestionable important struggle has had an important effect on the framing of LGBT subject-hood in human rights law. As these cases came to be framed, it is specific sexual acts that homosexual men are understood to be inherently disposed to and identified by.

Viewed through a gendered lens, this raises the question of whether the Court's view of the constitutive nature of gay male sexuality (albeit one that can be negatively characterised) stands in contrast to the way it has viewed lesbian sexuality. In W.B. v Germany, the Commission dismissed the applicant's complaint that different treatment of male and female sexuality in criminal law amounted to unlawful discrimination and found such difference to be justified on the basis of the need to protect health and morals. ${ }^{16}$ In 1975, the Federal Republic of Germany successfully argued in an age of consent case concerning laws that applied only to male same-sex activity, that

\footnotetext{
15 Frye, M., (1983), 'Lesbian Feminism and the Gay Rights Movement: Another View of Male Supremacy, Another Separatism', from Politics of Reality: Essays in Feminist Theory (Trumansburg, N.Y: Crossing Press). Available at: www.feminist-reprise.org/docs/fryegayrights.htm (accessed 15 February 2019).

${ }^{16}$ W.B. v Germany, no. 104/55, Commission Decision of 17 December 1955.
} 
"masculine homosexuals often constitute a distinct socio-cultural group with a clear tendency to proselytise adolescents"; ${ }^{17}$ with little discussion of its reasoning, the Commission accepted that the laws were not discriminatory because female (lesbian) sexuality was distinct and not in need of similar regulation. While such distinction in terms of legal regulations might of course be understood as being in certain ways advantageous to lesbian women, the particular question I am raising here is whether the distinction drawn between men and women's sexual agency has impacted on their subject-hood as rights bearers under the ECHR. The invisible subject cannot claim rights.

\section{Disaggregating the ' $L$ ' from the LGBT: Invisibility and Inadmissibility}

Disaggregating the 'L' from the 'GBT' cases reveals a quite startling disparity in the numbers of sexual orientation cases when considered by the applicants' gender. Paul Johnson has composed a list of the 125 LGBT cases that were brought from 1955 to mid-2015. ${ }^{18}$ Of those, only 17 were brought by an applicant who might be assumed to identify as a lesbian. ${ }^{19}$ The first ' $L$ ' case was not actually decided until 1986, thirty years after W.B. $v$ Germany. Indeed, finding the ' $L$ ' cases involves something of a quest; not looking for the well-known lead judgments, but, rather, trawling through those cases declared inadmissible or that were rejected on their merits. The overwhelming majority of those 17 ' $\mathrm{L}$ ' applications were not considered on their merits, but simply declared inadmissible: there was a finding of a violation in only five. More

\footnotetext{
${ }^{17}$ X. v Germany, no. 5935/72, Commission Decision of 30 September 1975, 3 Decision and Reports 51, at 56 .

${ }^{18}$ Johnson, P. (2015), 'Chronological List of Decisions and Judgments of the European Court of Human Rights and former European Commission of Human Rights in Respect of Homosexuality', available at http://echrso.blogspot.co.uk/2015/05/updated-list-of-complaints-to.html (accessed 15 February 2019).

19 The figure is possibly 20, but the gender and sexuality of the demonstrators for LGBT rights in three Article 10 and 11 cases was not specified.
} 
strikingly still, there was no finding of a violation in a case brought by a lesbian applicant until 1999, almost twenty years after Dudgeon: that case was Smith and Grady $v$ the United Kingdom, a ground-breaking case brought jointly with a male applicant to challenge the prohibition of homosexuals serving in the armed forces. ${ }^{20}$ It took until 2008 for the first finding of a violation in an 'L' case brought by a female applicant alone, in a matter concerning adoption. ${ }^{21}$

Lesbian invisibility before the Court defies conclusive explanations. Nonetheless, taking a closer look at how the Court has approached lesbian applicants reveals it has struggled with the framing of both the identity of lesbian applicants and their claims. It also raises questions about what might be lost in jurisprudential terms by the Court's clumsy grappling and blind-spots when it comes to female sexuality and subject-hood: lesbian women's own particular struggles have brought to its door a number of potentially ground-breaking cases. The first LGBT cases concerning discrimination in housing rights and employment rights were brought by lesbian applicants, as were the first applications addressing marriage equality, the parental rights and responsibilities of second parents, and adoption rights. I turn now to a brief overview of the ' $L$ ' cases to further explore these questions.

The history of 'L' cases begins a few years after the success in Dudgeon. The applicant in the earliest 'L' case, S. $v$ the United Kingdom (1986), was denied the right to inherit a council tenancy after the death of her female partner. ${ }^{22}$ In examining her complaint, the Commission displayed a revealing inability to conceive of female sexuality in the

\footnotetext{
${ }^{20}$ Smith and Grady, supra n. 6.

${ }^{21}$ E.B. v France (2008) 47 EHRR 21.

${ }^{22}$ S. $v$ the United Kingdom, no. 11716/85, Commission Decision of 14 May 1986, 47 Decisions and Reports 274.
} 
absence of a male. The following description of the applicant and her relationship is illuminating:

The applicant and Mrs. R. ran a joint household, sharing all expenses. They slept together in the same bed and had a lesbian relationship. The applicant dressed as a woman and Mrs. R. dressed as a man. It was generally known and accepted in the neighbourhood that they lived together in a lesbian relationship as man and wife and the applicant's representative has submitted a letter dated 6 March 1984 from the applicant's general medical practitioner stating that "for three years [Mrs. R] and [the applicant] have lived together in a lesbian relationship as 'man and wife'. ${ }^{23}$

The Commission held, following an earlier decision concerning a male couple, ${ }^{24}$ that the applicant's relationship with her deceased partner did not fall within the scope of the right to family life (Article 8). Nor was it an interference with her private life, as she now lived alone. Finally, in a particular interesting contortion of logic, it held that her right to a 'home' (also Article 8) was not interfered with because she had no legal right to the property in question. In a final blow, it found that if there were an interference with her home, this was necessary to protect the contractual rights of the landlord. It is also noteworthy that the Court relied on a medical authority figure to pronounce upon the applicant's sexuality and the nature of her relationship (thus, female sexuality, rather than being innate, is externally categorised and verified).

\footnotetext{
23 ibid at 274.

${ }^{24} X$. and Y. $v$ the United Kingdom, no. 9369/81, Commission Decision of 3 May 1983, 32 Decisions and Reports 220.
} 
C. and L.M. v United Kingdom (1989) was brought by an Australian citizen who formed a relationship in the UK with a British woman. ${ }^{25}$ The couple co-habited, and in 1989 'C' had a baby, 'L.M.'. C was threatened with deportation, which the Commission recognised would leave her "homeless, destitute", and dependent on "social security payments for the maintenance of herself and her child". ${ }^{26}$ It nonetheless found there to be no family life between couple (Article 8) and no unjustified interference with their private life (also Article 8): further, granting better guarantees to "traditional established families, rather than other established relationships like a lesbian partnership" did not violate the Convention. ${ }^{27}$ Although this case included the first Article 12 (right to marry) complaint from a same-sex couple, the Commission's cursory response was simply to assert that the right to marry did not extend beyond heterosexual relationships. A few years later, the Commission confirmed its approach in Kerkhoven, Hinke and Hinke v Netherlands, ${ }^{28}$ brought by a lesbian couple and their child. In Dutch law as it then stood, "only a man, whether the biological father or not, can recognise a child", meaning that the non-birth mother and child had no mechanisms for establishing legal ties. Predictably, given its earlier decisions, the response was that this did not amount to an interference with Convention rights. It is clear that the Commission struggled to recognise the rights of lesbian relationships, even those in which a child was being raised. Here, it is tempting to recall the words of Cheshire Calhoun: "Lesbians are not-women, engaged in nonsex, within nonrelationships that may constitute a nonfamily". ${ }^{29}$

\footnotetext{
${ }^{25}$ C. and L.M. $v$ the United Kingdom, no. 14753/89, Commission Decision of 9 October 1989.

26 ibid at 2.

27 ibid at 5 .

${ }^{28}$ Kerkhoven, Hinke and Hinke v Netherlands, no. 15666/89, Commission Decision of 19 May 1992.

${ }^{29}$ Cheshire Calhoun (April 1994), 'Separating Lesbian Theory from Feminist Theory', 104:3 Ethics 558581 at 580 .
} 
Lesbians face a particular form of intersectional discrimination that can operate to silence rights claims that stem from expressing their sexuality. In Morissens $v$ Belgium $(1988),{ }^{30}$ a teacher, having been open about her sexuality, commented on the authorities' failure to promote her while being interviewed on a radio programme (she effectively posed the question: "If two men are safe to appoint as head of a girls' school, why not me?"). Ms Morrisens was subsequently removed from her job, leading her to complain about an interference with her freedom of expression. The Commission found that the disciplinary action was not motivated by her homosexuality (suggesting its invisibility); rather, it was justified because of her particular role as a civil servant. In $X . v$ Switzerland, ${ }^{31}$ the Commission found that the female applicant's conviction for engaging professionally in homosexual relations did not engage her right to a private life. While male applicants have faced few questions about the nature of their relationships before their privacy rights are engaged, the Commission in rejecting her claim observed that "in this case the sexual relations which occasioned the conviction of the applicant were engaged in professionally in return for remuneration.". 32

The applicant in Craig $v$ United Kingdom $(2000)^{33}$ and her partner, L, lived apart every other week in order to satisfy a court order that L would not permit the children to come into contact with any person known to her to be lesbian, including the applicant. Ms Craig further had no right to intervene in the custody proceedings. In finding the application inadmissible, the Court observed that $\mathrm{L}$ had agreed to the order in question. The Court stated that the order aimed to protect the rights of the children and parents,

\footnotetext{
${ }^{30}$ Morissens v Belgium, no. 11389/85, Commission Decision of 3 May 1988, 56 Decisions and Reports 132 .

${ }^{31}$ X. v Switzerland, no. 11680/85, Commission Decision of 10 March 1988, 55 Decisions and Reports 178.

32 ibid at 180 .

${ }^{33}$ Craig $v$ the United Kingdom, no. 45396/99, Admissibility Decision of 7 March 2000.
} 
failing to consider the clear detrimental effect it would have on the particular relationships in question. The Court also held that the applicant's argument that her future employment would be affected by being named in family court proceedings was unconvincing and not supported by evidence.

\section{The On-going Struggle for Recognition}

While the Court has come to be much more sympathetic to LGBT claims in recent years, I argue that the invisibility and clumsy framing of lesbian sexuality and relationships is still apparent. As previously mentioned, the first successful ' $L$ ' case was Smith and Grady $v$ the United Kingdom, ${ }^{34}$ which concerned the applicants' discharge from the armed forces on the basis of their sexual orientation. The case is noteworthy for the progress it makes in terms of non-discrimination. The Court held that: '... when the relevant restrictions concern "a most intimate part of an individual's private life", there must exist "particularly serious reasons" before such interferences can satisfy the [Convention]...? ${ }^{35}$ While this judgment is undoubtedly groundbreaking, it is worth noting that Jeanette Smith's success came in conjunction with a male applicant. Far less well-known is a contemporaneous case brought by a lesbian applicant alone, Fleming $v$ the United Kingdom. ${ }^{36}$ Ms Fleming was the partner of a woman discharged from the RAF on the basis of her sexual orientation. The coincidence of facts strongly suggests that this applicant was in fact the partner of Jeanette Smith, although this is not stated. Ms Fleming, although not in the RAF, was interviewed about their relationship, and asked intrusive, intimate and distressing questions (including about her relationship with her foster daughter). Of this

\footnotetext{
${ }^{34}$ Smith and Grady, supra n. 6.

35 ibid at para. 89 .

${ }^{36}$ Fleming $v$ the United Kingdom, no. 33987/96, Commission Decision of 20 May 1997.
} 
experience, she said it left her "profoundly distressed, that she felt abused and shamed and that she was given no warning or notice of the nature or content of the questions which were to be raised". ${ }^{37}$ Despite the treatment she was subjected to, she had no remedy in Strasbourg: the Commission dismissed her case for being out of time, arguing that the judicial review proceedings brought by her partner could not have amounted to a remedy for the applicant.

E.B. $v$ France $(2008)^{38}$ is notable for being the first successful case brought by an ' $L$ ' applicant alone. The Court upheld her complaint that the authorities' refusal of her application for approval to adopt because of a lack of paternal referent was discriminatory against her as a single person seeking to adopt. Certain aspects of this judgment are remarkable; it is one of the most far-reaching of the LGBT cases. The Court accepted that while some reasons for rejecting the application were legitimate, the process was contaminated by implicit homophobia: "The influence of the applicant's avowed homosexuality on the assessment of her application has been established and...was a decisive factor leading to the decision to refuse her authorisation to adopt". ${ }^{39}$ However, while the applicant's own privacy rights relating to her sexuality were recognised (itself a hugely important step, although decades late), her lesbian relationship and emotional attachments were not. The Court accepted that rejecting her application because of her partner's apparent lack of interest in the adoption was legitimate: "this ground, which has nothing to do with...the applicant's sexual orientation, is based on a simple analysis of the known, de facto situation and its consequences for the adoption of a child". ${ }^{40}$ The Court displays a striking failure to

\footnotetext{
37 ibid at 2.

${ }^{38}$ E.B., supra n. 21.

${ }^{39} \mathrm{ibid}$ at para. 89 .

40 ibid at para. 78 .
} 
imagine what impact the legal prohibition of joint adoption must have had on the couple: one might think there were understandable reasons for the applicant to emphasise her partner's lack of planned involvement in raising a child. The prohibition itself was unquestionably detrimental to the planning of a shared family life, a question the Court left unexplored.

While there were several unsuccessful cases brought by lesbian applicants seeking to protect their families and relationships, it was in a case brought by a male same-sex couple that the Court first began to recognise relationship rights. In Schalk and Kopf (2010), the Court - referring to the "rapid evolution of social attitudes towards samesex couples" in Europe ${ }^{41}$ - held for the first time that the male couple could establish family life under Article 8. A few months later in J.M. v the United Kingdom (2011), ${ }^{42}$ the applicant, who was in a same-sex relationship, argued that the calculations of her child support payments paid to ex-husband with respect to their children had discriminated against her because new relationship was not legally recognised. While finding a discriminatory interference with her property rights (Article 1, Protocol 1), the Court held that there was no need to consider the question of any interference with the applicant's family or home life. This was a particularly unfortunate approach in light of its recent decision in Schalk and Kopf. In the words of three dissenting judges: "J.M. offered a good opportunity to contribute to the emerging change in our case-law. Regrettably, the majority chose to avoid taking a clear position". ${ }^{43}$

\footnotetext{
${ }^{41}$ Supra n. 6 at para. 93.

${ }^{42}$ J.M. $v$ the United Kingdom, (2011) 53 EHRR 6.

${ }^{43}$ Concurring Opinion of Judges Garlicki, Hirvelä and Vučinić at para. O-14.
} 
The applicants in Gas and Dubois v France (2012) ${ }^{44}$ were in a relationship and had been cohabiting since 1989; Ms Dubois gave birth to a daughter, conceived by anonymous donor insemination, in 2000. Although the women entered a civil partnership in 2002, French law treated civil partners and married couples differently, and consequently Ms Gas had no way of establishing legal ties to their daughter. Her application for a simple adoption order was denied. In dismissing the applicants' complaint, the Court noted that marriage confers a special status, and denying the applicants access to that status did not amount to a violation of their rights. $X$. \& Ors $v$ Austria (2013), ${ }^{45}$ also concerned second-parent adoption by the non-birth mother, but the outcome was somewhat different. While reiterating that the Convention does not oblige States to extend second-parent adoption to unmarried couples, the Court held that because Austria had chosen to do so, it must not thereafter discriminate against same-sex couples. While a useful reaffirmation of equality, the judgment did not disrupt exclusive approaches to marriage and, further, created only a limited (nondiscrimination) obligation on States. Even in a judgment that found for the applicant, seven partly dissenting judges expressed fearful views about women being in a relationship that excludes men: "[The child] has a mother and a father: what best interests would have been served had his father been replaced by his mother's partner?"46

In Boeckel and Gessner-Boeckel v Germany (2013), ${ }^{47}$ a civil-partnered lesbian couple complained they could not enter both names onto their child's birth certificate. In order

\footnotetext{
${ }^{44}$ Gas and Dubois v France, (2014) 59 EHRR 22.

${ }^{45}$ X. v Austria, (2013) 57 EHRR 14.

${ }^{46}$ Joint Partly Dissenting Opinion of Judges Casadevall, Ziemele, Kovler, Jočienė, Šikuta, De Gaetano and Sicilianos, ibid at OII-8.

${ }^{47}$ Boeckel and Gessner-Boeckel v Germany, no. 8017/11, Admissibility Decision of 7 May 2013.
} 
for the non-birth mother to create legal ties, adoption would have been necessary. For the Court, it seemed obvious that the applicants' situation could not be equated to that of a married opposite-sex couple:

...in case one partner of a same-sex partnership gives birth to a child, it can be ruled out on biological grounds that the child descended from the other partner. The Court accepts that, under these circumstances, there is no factual foundation for a legal presumption that the child descended from the second partner. ${ }^{48}$

In short, the discrimination results, the Court argued, not from the sexuality of the applicants (which is effectively made invisible), but rather from their unmarried status. This reflects Otto's observation that women's sexuality in international law is valued little outside of married heterosexuality and reproduction. ${ }^{49}$ This seems to indicate a heteronormative and patriarchal approach to applications by lesbians and their families, which serves to undermine the progress that is being made elsewhere towards LGBT rights.

The effects of the Court's approach have continued to be felt in three more recent inadmissibility decisions. In Karine Hallier \& Ors $v$ France, ${ }^{50}$ the non-birth mother in a lesbian couple had been denied paternity leave. In declaring the application manifestly ill-founded, the Court accepted that the purpose behind paternity leave was to address inequality between men and women. It found that was no discrimination because a male partner who was not a biological father would also not have been entitled to paternity

\footnotetext{
48 ibid at 8.

${ }^{49}$ Otto, D., (2014) 'Between Pleasure and Danger: Lesbian Human Rights', 6 European Human Rights Law Review 618-628 at 620.

${ }^{50}$ Karine Hallier \& Ors v France, no. 46386/10, Admissibility Decision of 12 December 2017.
} 
leave. Here again, the Court's analysis effectively rendered the particularities of lesbian relationships invisible. In Charron and Merle-Montet $v$ France (2018), ${ }^{51}$ a married female couple challenged the relevant Bioethics Law that denied medically assisted reproduction to same-sex couples. The Court rejected the complaint for non-exhaustion of domestic remedies, even though a successful constitutional complaint seemed an unlikely outcome. It is worth remarking that in Oliari \& Ors v Italy $(2017)^{52}$ - a groundbreaking successful complaint brought by three male same-sex couples - the Court accepted the complaint about an absence of relationship recognition in Italy was admissible even in the absence of a prior constitutional challenge because it would have had a limited chance of success. More recently still, in Bonnaud \& Lecoq v France (2018), ${ }^{53}$ the Court rejected a lesbian couple's complaint that they had each been denied the possibility of exercising parental responsibility over their partner's biological child, a decision taken in spite of their civil partnership and the fact that both children had been born into the relationship. Adopting familiar reasoning, the Court held the couple had been treated as any unmarried couple would and that therefore the decision was not based on their sexual orientation.

\section{Concluding Observations}

The struggle for LGBT rights in Europe has been hard fought and is on-going, and it is neither easy nor comfortable offering a critique of it. This paper has been driven by a keen awareness of the exclusion and marginalisation of lesbian women from international human rights in general, and the Court's case-law in particular. I am also critical of the general failure to consider how developments in LGBT rights impact

\footnotetext{
${ }^{51}$ Charron and Merle-Montet v France, no. 22612/15, Admissibility Decision of 8 February 2018.

${ }^{52}$ Oliari \& Ors v Italy, (2017) 65 EHRR 26.

${ }^{53}$ Bonnaud and Lecoq v France, no. 6190/11, Admissibility Decision of 6 February 2018.
} 
lesbian women. Discussing LGBT cases in aggregate can serve to mask the experience that women have had in Strasbourg. In the words of Dianne Otto, “...discrimination on the grounds of gender and sexual orientation can combine to produce distinctive forms of discrimination that might be described specifically as 'lesbian". ${ }^{54}$ Women's voices and experiences are, I suggest, struggling to find a platform in international human rights law. This diminishes the potential of the Court's jurisprudence to address genderbased injustice. In the words of Johanna Bond, "The notion that men and women within different communities experience discrimination based on sexual orientation differently is critical to a richer understanding of human rights violations related to gender and sexuality." 55

While conceptualising the private sphere has been of great significance for feminists, the cases examined in this paper suggest that the private sphere - existing as it does only as a reflection of, and point of contrast to, men's lives - has been of limited usefulness for lesbian women. The Court construction of the LGBT application has also had significant implications for relationship claims. While relationships are generally treated as private and rational choices made by autonomous adults, the Court has struggled to recognise the autonomy and subject-hood of lesbian women. Additionally, the Court continues to place emphasis on the special nature of marriage: trans applicants and lesbian women have discovered to their cost that their marriages are only 'acceptable' in so far as they can mirror heteronormative patriarchal structures. Further, in spite of the caring role most societies ascribe to women, the significance of biological ties in relation to those raising children is at the centre of many of the court's judgments

\footnotetext{
${ }^{54}$ Otto, supra n. 49 at 620.

55 Bond, J.E. (2003), 'International Intersectionality: A Theoretical and Pragmatic Exploration of Women's International Human Rights Violations', 52 Emory Law Journal 71-186 at 136-7.
} 
brought by lesbian parents. Ultimately, the Court is bound by an essentially patriarchal framework when approaching LGBT cases; the pressing question is whether it is possible for it to imagine and create an alternative framework that better accommodates lesbian women's lives and experiences.

How, then, does one address a perceived 'absence' and consequent invisibility? Judith Butler may offer some useful answers. In Bodies that Matter, she writes of the need to search for a lesbian phallus:

...to speak of the lesbian phallus as a possible site of desire is not to refer to an imaginary identification and/or desire that can be measured against a real one; on the contrary, it is simply to promote an alternative imaginary to a hegemonic imaginary and to show, through that assertion, the ways in which the hegemonic imaginary constitutes itself. ${ }^{56}$

Certainly the Court seems to assume an absence in lesbian relationships that renders them invisible; this needs to be challenged in order for progress to be made. One pressing concern that readily springs to mind is how vulnerable this invisibility renders lesbians seeking asylum due to persecution arising from their sexuality. Finally, in the rush to celebrate relationship recognition and push forward the LGBT rights agenda, little attention has been paid to feminist critiques of marriage as a site of female oppression. ${ }^{57}$ It seems imperative that these voices are listened to in the next phase of the struggle, in which marriage rights seem certain take centre-stage. Ultimately, this

\footnotetext{
${ }^{56}$ Butler, J. (1993), Bodies that Matter: On the Discursive Limits of "Sex" (London: Routledge) at 91.

${ }^{57}$ See, for example, Auchmuty, R. (2004), 'Same-Sex Marriage Revived: Feminist Critique and Legal Strategy', 14:1 Feminism and Psychology 101-126; Barker, N. (2012), Not the Marrying Kind: A Feminist Critique of Same-Sex Marriage (Basingstoke: Palgrave Macmillan).
} 
brief survey suggests that the ECHR's approach to LGBT cases has been neither gender-sensitive nor intersectional. Lesbian women have been frequently over-looked and significantly let down by the Court: posing the ' $L$ ' question highlights the need for alternative approaches to be taken. 